\title{
Koraszülött gyermekek kétéves kori pszichomotoros fejlődése társas-környezeti tényezők függvényében
}

\author{
Kenyhercz Flóra - Nagy Beáta Erika dr. \\ Debreceni Egyetem, Általános Orvostudományi Kar, Gyermekgyógyászati Intézet, Debrecen
}

\begin{abstract}
Bevezetés: A koraszülött gyermekek fejlődésének vizsgálata népegészségügyileg kiemelt terület, mivel százalékos arányuk nem csökken számottevőn az orvostudomány előrehaladásával. Célkitüuzés: A koraszülött gyermekek pszichomotoros fejlettségi szintjének leírása potenciálisan befolyásoló környezeti tényezőkkel összefüggésben. Módszer: 2500 gramm alatti születési súlyú, a vizsgálat idején kétéves kisgyermek $(\mathrm{n}=75)$ pszichomotoros fejlődése, otthoni környezetének minősége, szociodemográfiai háttere. Eredmények: A biológiai rizikót jelentő kisebb születési súly és hosszabb kórházi tartózkodás alacsonyabb fejlődési kvócienssel társul. A gyermeknélkülözés, valamint a gyermeket alacsony mértékben érő kognitív stimuláció és anyai empátia negatívan hat a fejlődési hányadosra, születési súlytól függetlenül. Az alacsony szocioökonómiai státuszt jellemző változók növekvő számú megjelenése, mint alacsony anyai iskolázottság, apa munkanélkülisége vagy kisebbségi csoporthoz tartozás, erősödő teljesítményromlással társul. Következtetés: A vizsgált társas-környezeti tényezők, a biológiai rizikón túl, már kétéves korban befolyásolják a koraszülött gyermekek fejlődését. A szerzők ajánlják a környezeti rizikótényezők mentén a legveszélyeztetettebbek minél korábbi szưrését, valamint fejlesztő intervenciók biztosítását, így megelőzve későbbi mentális, motoros nehézségek kialakulását. Orv. Hetil., 2017, 158(1), 31-38.
\end{abstract}

Kulcsszavak: koraszülés, alacsony születési súly, pszichomotoros fejlődés, kora gyermekkor

\section{Examination of psychomotor development in relation to social-environmental factors in preterm children at 2 years old}

Introduction: The development of children born prematurely is an important aspect in public health, because preterm birth rates are not decreasing with the development of medical sciences. Aim: Description of psychomotor development of preterm children related to potentially influencing environmental factors. Method: Children born below 2.500 grams at the age of two $(n=75)$. Psychomotor development, quality of home environment, socio-demographic background were measured. Results: Lower birth weight was associated with lower development quotients. Psychomotor development was also negatively affected by child deprivation, low levels of cognitive stimulation and maternal empathy, regardless of birth weight. Increased performance loss was found related to lower sociodemographic variables, such as low maternal education or ethnicity. Conclusion: Psychomotor development of 2-year-old premature children is affected by the examined social-environmental factors. We recommend the screening and developmental interventions for premature children as early as possible, thus preventing difficulties in mental and motor development in the future.

Keywords: preterm birth, low birth weight, psychomotor development, early childhood

Kenyhercz, F., Nagy, B. E. [Examination of psychomotor development in relation to social-environmental factors in preterm children at 2 years old]. Orv. Hetil., 2017, 158(1), 31-38.

(Beérkezett: 2016. szeptember 30; elfogadva: 2016. november 10.) 
$\mathrm{BQ}$ = beszédkészség-hányados; ELBW = extrém kis születési súly; $\mathrm{FQ}=$ fejlődési hányados; Korr. $\mathrm{FQ}=$ korrigált fejlődési hányados; $\mathrm{KQ}=$ szenzomotoros koordinációs hányados; LBW = kis születési súly; $\mathrm{PQ}=$ posturalis adaptációs hányados; SES = szocioökonómiai státusz; SzQ = szociabilitáshányados; VLBW = igen kis születési súly

Az utóbbi évtizedek nemzetközi és magyar szakirodalma a kora gyermekkor fokozott szerepére hívja fel a figyelmet a későbbi kognitív, mentális és szomatikus fejlődés tekintetében. A kisgyermekkor paradoxonjának tekinthető, hogy miközben ekkor a legerőteljesebb a gyermek fejlődése, egyben a legsérülékenyebb is [1]. Jelen áttekintés egy, a kora gyermekkortól, sőt a születés pillanatától nehezebb fejlődési körülmények között élő gyermekeket helyez a középpontba, mégpedig a koraszülött és alacsony születési súlyú kisgyermekek csoportját. A WHO 2015-ös jelentése alapján évente 15 millió újszülött jön a világra a 37 . gesztációs hét előtt, s körükben megközelítőleg 1 millió haláleset történik az ötödik életév betöltését megelőzően. A peri- és neonatalis morbiditás és mortalitás fö okaként tehát a koraszülés jelölhető meg $[2,3]$. 184 országot tekintve jelenleg a koraszülöttek aránya 5 és 18\% között változik, hazánk 8-11\%-os mutatói a középkategóriába esnek, azonban napjainkban folyamatos az emelkedés [2,4]. A koraszülés okait tekintve még ma sem tudunk biztosat állítani, valószínűsíthetően multifaktoriális háttérről beszélhetünk [4]. Következményeit vizsgálva számos tanulmány rávilágított, hogy e rizikócsoport tagjai a kognitív, a mentális, valamint a motoros fejlődésében egyaránt veszélyeztetett [5, 6], illetve körükben már 4-6 éves korban nagyobb esélylyel tapasztalhatóak viselkedési, figyelmi és érzelmi zavarok, szomatikus panaszok, alacsonyabb intellektus és szociális deficit $[7,8]$.

Kutatásunk során a koraszülöttség kritériumait a WHO 1961-es ajánlása alapján határoztuk meg, azaz idesoroltunk minden olyan élő újszülöttet, akinek a kihordási ideje nem haladta meg a 37 hetet, függetlenül a születési súlytól $[3,9]$. A koraszülöttség alsó határaként továbbá 1997 óta, a CLIV. egészségügyi törvénynek megfelelően, a 24. gesztációs hetet jelöltük meg, mivel a gyermek vitális paramétereinek éréséből adódóan ez tekinthető az életben tarthatóság határának $[4,10]$. A perinatalis veszélyeztetettségek vizsgálatunk során alkalmazott másik kategóriája az alacsony születési súly, amely a koraszülöttséget csak részben fedi le [9]. Az újszülöttkori optimális testtömeg 3000 és 4000 gramm közötti, így a 40. terhességi hétre születettek súlya átlagosan 3340 gramm, hoszszuk $51 \mathrm{~cm}$, fejkörfogatuk pedig $35 \mathrm{~cm}[4,11]$. Alacsony születési súlyúnak a 2500 grammot el nem érő újszülötteket tekintettük, s közöttük az Egészségügyi Világszervezet (WHO) 1961-ben kiadott meghatározása alapján három kategóriát különböztettünk meg [4]:

- kis születési súly (1500-2499 gramm): low birth weight (LBW);
- igen kis születési súly (1000-1499 gramm): very low birth weight (VLBW);

- extrém (vagy „igen-igen”) kis születési súly (1000 grammon aluli): extreme low birth weight (ELBW);

- új kategória a „micro preemie” újszülöttek, akik 800 gramm alatti születési súlyúak, vagy a 26. gesztációs hét előtt jönnek a világra [12].

\section{A koraszülés lehetséges szövődményei, következményei}

A koraszülött gyermekek idegrendszere s egész szervezete éretlen állapotban kényszerül a külső környezeti feltételek közötti múködésre, s így az alkalmazkodás nagy megterhelést jelent számukra [9, 13]. E gyermekek „érett” társaikhoz képest biológiai rizikóval jönnek a világra, így a későbbiekben nagyobb eséllyel tapasztalható náluk intellektuális, érzelmi vagy szociális deficit [5]. Egy 2011-es vizsgálat során Woythaler és mtsai 6300, időre született és 1200 késői koraszülöttet (34-36. gesztációs hét) vizsgáltak kétéves korban. Eredményeik alapján a koraszülöttek csoportjában $52 \%$-kal valószínúbben jelent meg súlyos, valamint $43 \%$-kal valószínúbben enyhe mentális elmaradás. A vizsgálat során hasonló eredményeket találtak a mozgásos képességekkel kapcsolatban is [6]. Egy 2012-es tanulmányban 1000, időre született és 600, késői koraszülött gyermek adatait elemezve a koraszülött gyermekek körében gyakoribb volt a szorongás, a depresszió, az agresszió, valamint a figyelemzavar megjelenése is. Összességében a korábban érkezettek közül hozzávetőlegesen kétszer többen szenvedtek viselkedési és érzelmi zavaroktól, valamint szomatikus panaszoktól [7]. Nicole Talge késői koraszülött gyermekeknél figyelte meg, hogy kétszer nagyobb eshetőséggel szenvednek figyelemhiányos tünetegyüttestől, mint „érett” társaik, továbbá a 34-36 hetes gesztáció a hatéves kori alacsonyabb színvonalú intellektuális fejlődés szempontjából is nagyobb kockázatot jelent [8].

Igen kis születési súlyú gyermekeknél finom motoros és vizuomotoros performációs eltéréseket is találtak, habár fejlődésneurológiailag a csecsemőkori fejlődésük látszólag teljesen normális volt [14]. Egy 1991-es magyar kutatásban extrém kis súlyú koraszülött gyermekeknél, 8-11 éves korban, a szüleik elmondása alapján három viselkedésformát találtak szignifikánsan jellemzőnek rájuk: a követelőzést, az aktivitás szélsőségeit és a kiegyensúlyozatlanságot. A tanáraik beszámolóiból pedig az derült ki, hogy időben született társaikhoz képest éretlenebb, kevésbé körültekintő és célratörő, valamint alacsonyabb önkontrollal rendelkező gyerekek benyomását keltik [15]. Constantinou és mtsai az extrém kis születési súlyú (ELBW) és a nagyon kis születési súlyú (VLBW) gyermekek mentális, valamint pszichomotoros fejlődésében is eltérést találtak 12, 18 és 30 hónapos korban is, a magasabb születési súlyú csoport (VLBW) javára [16]. Egy 2010-es tanulmányban pedig késői koraszülötteknél nemi különbségeket mutattak ki a 12 és 18 
hónapos korban mért pszichomotoros teljesítményben, mégpedig a lányok javára [17].

Több longitudinális tanulmány rávilágít, hogy azonos perinatalis inzultus (például: alacsony születési súly) pszichikus fejlődésre gyakorolt hatása az eltérő környezeti feltételek függvényében változhat. Az utóbbi két évtizedben egyre több kutatás bizonyítja, hogy a szociális környezet hatásai (környezeti rizikó) enyhíthetik vagy súlyosbíthatják a későbbi fejlődési zavarok alakulását $[18,19]$.

\section{Módszer}

\section{Vizsgálati minta}

Az alacsony születési súlyú kisgyermekek vizsgálatát a Debreceni Egyetem Klinikai Központjának neonatológiai szakrendelésével történő együttmúködés során, a koraszülött-utógondozói státuszvizsgálat keretein belül végeztük. Az adatgyưjtés 2015 júniusától 2016 januárjáig zajlott, amelynek során 139, korrigáltan a második életévét betöltött koraszülött gyermek került behívásra, akik a Debreceni Egyetem, Klinikai Központ Szülészeti és Nőgyógyászati Klinikáján 2500 gramm alatti súllyal jöttek a világra. A vizsgálaton ténylegesen megjelent 94 gyermek adatait tovább szúkítettük, s kiszürtük a 30 hónapot betöltötteket, az életkori átlagok megfelelésének érdekében, valamint a súlyos látási (retinopathia prematurorum - ROP okozta vakság) és hallási (siketség) rendellenességekkel küzdő gyermekeket, hiszen esetükben a Brunet-Lézine-skála által mért fejlődési kvóciens nem mutatott volna reális értéket.

A vizsgálati mintába végül 75 , a második életévét betöltött, koraszülött gyermeket vontunk be, s a WHO csoportosítása mentén, születési súlyuk alapján, a következő három kategóriába soroltuk: kis születési súlyú (1500-2499 gramm), LBW ( $\mathrm{n}=26)$, igen kis születési súlyú (1000-1499 gramm), VLBW ( $\mathrm{n}=23)$, extrém kis születési súlyú (1000 grammon aluli), ELBW ( $=26)$.

\section{Vizsgálati eszközök}

1. A kisgyermekek pszichomotoros fejlettségi szintjét Brunet-Lézine csecsemö- és kisgyermek-fejlödési skála (Brunet-Lézine's Psychomotor Development Scale, 1980) segítségével mértük fel, amely jelenleg az egyetlen standardizált csecsemőfejlődés-diagnosztikai teszt hazánkban. A mérőeszköz a következő négy részterületet vizsgálja: posturalis adaptáció, szenzomotoros koordináció, beszédképesség és szociabilitás [20]. A fejlődési skála kísérleti helyzetben, a gyermek által elvégzendő próbákat, valamint a gyermek spontán viselkedésére vonatkozó, a szülő által megválaszolandó kérdéseket tartalmaz [21].

2. Az UNICEF Kutatási Központ 10-es számú tanulmánya alapján az egyik mérőeszközünk a Gyermeknélkülözési Index (UNICEF Child Deprivation Index, 2012) volt, amely az alapvető szülkségletek meglétére vagy azok hiányára vonatkozó állításokat tartalmazó lista, ami 1-18 éves korú gyermekek körében alkalmazható. Ennek értékelése mentén a gyermek akkor tekinthető nélkülözőnek, ha a listából kettő vagy több tényező nem adott az életében. Idetartoznak többek között a fiziológiai szükségletek (például: napi háromszori étkezés, megfelelő ruháztatás), a kognitív szükségletek (a gyermek tudásszintjének megfelelő könyvek vagy játékok megléte), valamint a biztonság szükséglete (nyugodt, veszélyforrásoktól mentes hely biztosítása a gyermek játéktevékenységéhez) is. A kérdőív tehát a gyermek létfenntartási, oktatási és tanulási, valamint társas szükségleteinek betöltöttségét méri fel [22].

3. Vizsgáltuk továbbá a gyermek otthoni környezetének minőségi jellemzőit a HOME-leltár rövidített verziójának (The Short Form of the HOME Inventory; HOME-SF; Bradley és Caldwell, 2003) segítségével. A mérőeszköz két alkategóriát térképez fel: a gyermeket érő kognitív stimulációt (például: „Hetente milyen gyakran szokott felolvasni a gyermeknek?"), valamint az anyai érzelmi támogatás, melegség mértékét a gyermek felé (például: „Egy nap hányszor eszik együtt a gyermek az anyával és az apával?”) [23].

4. A kérdőívcsomag elejére egy szociodemográfiai adatokat feltérképező kérdéssorozatot állítottunk össze, amelynek összetevői a következők voltak [1]: a szülők iskolai végzettsége, foglalkoztatottsága, a család szerkezete, lakóhelye, szubjektív és objektív anyagi helyzete, valamint etnikai hovatartozása. Az 1993-as Samerofftanulmány 10 rizikótényezője közül a gyermek intelligenciájának fejlődésére irányuló hatások tekintetében a Többszörös Rizikó Index következő öt elemét térképeztük fel: kisebbségi csoporthoz tartozás, családfó foglalkoztatottsága (munkanélküli, közmunkás), anya alacsony iskolázottsága ( 8 általános vagy attól alacsonyabb iskolai végzettség), család mérete (négy vagy több gyermek), apa hiánya a családban $[24,25]$.

\section{Az adatok statisztikai feldolgozása}

Az adatok statisztikai elemzéséhez az IBM SPSS Statistics v20 programot használtuk. Az adatbevitelt követően a változók eloszlásának normalitását egymintás Kolmogorov-Szmirnov-teszttel, valamint egymintás $\chi^{2}$-próbákkal teszteltük. A vizsgálat során azt találtuk, hogy $\mathrm{p}<0,05$ szignifikanciaszint mellett a változóink nagy része nem követi a normális eloszlás mintázatát, így a későbbi elemzések során nemparaméteres statisztikai eljárásokat alkalmaztunk.

\section{Eredmények}

\section{Átlagok és szórás}

A vizsgálati mintába sorolt kisgyermekek $(\mathrm{n}=75)$ születési súlya 400 és 2490 gramm közé esett $(M=1387,87$, 
$\mathrm{SD}=590,87)$, a gesztációs idő szintén alacsony értéket mutatott $(\mathrm{M}=30,36, \mathrm{SD}=4,21)$, hiszen majdnem minden alacsony súllyal született gyermek koraszülött volt. A születés után mért Apgar-eredmények közül az egy perc utáni értékek voltak a legalacsonyabbak $(\mathrm{M}=7,21$, $\mathrm{SD}=2,06)$, s az öt- $(\mathrm{M}=8,34, \mathrm{SD}=1,15)$, illetve a tízperces adatok $(M=8,67, S D=0,91)$ már erősebb életfunkciókra utaltak. A gyermekek átlagéletkora a vizsgálat idején 26,2 hónap $(M=785,75$ nap, $S D=35,55)$, korrigáltan pedig 23,8 hónap $(\mathrm{M}=714,35$ nap, $\mathrm{SD}=$ $32,97)$ volt. A mintában a nemek megoszlása megközelítőleg azonos volt (fiúk: $\mathrm{n}=38$; lányok: $\mathrm{n}=37$ ). A célváltozók valódi életkorral számolt átlagértékei, melyeket az elemzések során alkalmaztunk a következők voltak: $\mathrm{FQ}(\mathrm{M}=84,72, \mathrm{SD}=15,13), \mathrm{PQ}(\mathrm{M}=86,63, \mathrm{SD}=$ $16,83), \mathrm{KQ}(\mathrm{M}=83,77, \mathrm{SD}=16,34), \mathrm{BQ}(\mathrm{M}=81,69$, $\mathrm{SD}=17,15), \mathrm{SzQ}(\mathrm{M}=89,33, \mathrm{SD}=16,24)$.

\section{A születési súly és a nem kapcsolata a pszichomotoros teljesitménnyel}

Feltételezésünkhöz hűen pozitív, közepesen erős korrelációval írható le a két változó kapcsolata, azaz a kisebb születési súly alacsonyabb kétéves kori teljesítménnyel járhat együtt. Az egyes részképességek vizsgálata hasonló irányú és erôsségú szignifikáns korrelációt mutatott a születési súllyal összefüggésben. A legerősebb együttjárás a szenzomotoros koordinációs készséggel (KQ) mutatkozott $(\mathrm{r}=0,535, \mathrm{p}<0,001)$, a sorban ez után a nagymozgásos (PQ) $(\mathrm{r}=0,479, \mathrm{p}<0,001)$, majd a szociális $(S z Q)(r=0,465, p<0,001)$ és végül a beszédkészség (BQ) $(\mathrm{r}=0,391, \mathrm{p}<0,001)$ következett (1. táblázat).

A minta vizsgálata során az FQ tekintetében szignifikáns különbséget találtunk a nemek szerinti csoportosításkor. Független mintás Mann-Whitney-féle U-próba alkalmazása során mind a négy részképesség területén szignifikáns differencia mutatkozott, méghozzá a lányok javára (2. táblázat).

\section{Társas-környezeti tényezök kapcsolata a pszichomotoros teljesitménnyel}

A vizsgált társas-környezeti tényezők közül a gyermeknélkülözés szignifikáns összefüggést mutatott a kétéves kori pszichomotoros teljesítménnyel. Mindhárom súlykategóriában jobb teljesítményt nyújtottak (FQ) azok a gyermekek, akik nem élnek nélkülözésben. Szignifikáns különbséget azonban csak a két magasabb súlykategóriájú nélkülöző és nem nélkülöző gyermekek teljesítménye között találtunk (LBW: $\mathrm{p}=0,016$; VLBW: $\mathrm{p}=0,002$ ), azonban tendenciájában a legalacsonyabb súlycsoport esetében is kimutatható hasonló eredmény (ELBW: $\mathrm{p}=$ 0,113). A részképességek tekintetében a Spearman-féle rangkorrelációs elemzés alapján a gyermekek nélkülözése a legerősebb együttjárást az $\mathrm{SzQ}$-val $(\mathrm{r}=0,466$, $\mathrm{p}<0,0005)$ és a PQ-val $(\mathrm{r}=0,446, \mathrm{p}<0,0005)$ mutatta.
1. táblázat | Részképességek átlagértékeinek bemutatása a három születési súlykategóriában (M, p-value)

\begin{tabular}{llllll}
\hline & $\begin{array}{l}\text { Teljes } \\
\text { minta } \\
(\mathrm{n}=75)\end{array}$ & $\begin{array}{l}\text { Extrém } \\
\text { kis súly } \\
(\mathrm{n}=26)\end{array}$ & $\begin{array}{l}\text { Igen } \\
\text { kis súly } \\
(\mathrm{n}=23)\end{array}$ & $\begin{array}{l}\text { Kis súly } \\
(\mathrm{n}=26)\end{array}$ & $\begin{array}{l}\text { Szignifi- } \\
\text { kancia* }\end{array}$ \\
\hline $\begin{array}{l}\text { Fejlódési } \\
\text { kvóciens (FQ) }\end{array}$ & 84,7 & 77 & 83,8 & 93,2 & $\mathrm{p}<0,0005$ \\
$\begin{array}{l}\text { Posturalis } \\
\text { adaptáció (PQ) }\end{array}$ & 86,6 & 78,8 & 85,9 & 95,1 & $\mathrm{p}=0,001$ \\
$\begin{array}{l}\text { Szenzomotoros } \\
\text { koordináció } \\
\text { (KQ) }\end{array}$ & 83,8 & 75,1 & 82,3 & 93,7 & $\mathrm{p}<0,0005$ \\
$\begin{array}{l}\text { Beszédkészség } \\
\text { (BQ) }\end{array}$ & 81,7 & 74,7 & 80,4 & 89,8 & $\mathrm{p}=0,005$ \\
$\begin{array}{l}\text { Szociális } \\
\text { készség (SzQ) }\end{array}$ & 89,3 & 81,1 & 90,4 & 96,6 & $\mathrm{p}=0,002$ \\
\hline
\end{tabular}

*Független mintás Kruskal-Wallis-próba, p<0,05.

2. táblázat |A részkvóciensek nemek közötti különbségeinek bemutatása (M, p-value)

\begin{tabular}{llll}
\hline & $\begin{array}{l}\text { Lányok } \\
(\mathrm{n}=37)\end{array}$ & $\begin{array}{l}\text { Fiúk } \\
(\mathrm{n}=38)\end{array}$ & Szignifikancia* \\
\hline $\begin{array}{l}\text { Fejlődési kvóciens (FQ) } \\
\begin{array}{l}\text { Posturalis adaptáció } \\
(\mathrm{PQ})\end{array}\end{array}$ & 90,1 & 79,5 & $\mathrm{p}<0,001$ \\
$\begin{array}{l}\text { Szenzomotoros } \\
\text { koordináció (KQ) }\end{array}$ & 88,9 & 80,9 & $\mathrm{p}<0,001$ \\
$\begin{array}{l}\text { Beszédkészség }(\mathrm{BQ}) \\
\text { Szociális készség }(\mathrm{SzQ})\end{array}$ & 88 & 78,8 & $\mathrm{p}=0,007$ \\
\hline
\end{tabular}

*Független mintás Mann-Whitney-féle U-próba, p<0,05.

A HOME-leltár összesített pontszáma - amelynek összetevői a kognitív stimuláció és az anyai empátia mértéke - és az FQ között közepesen erős, pozitív összefüggést találtunk $(\mathrm{r}=0,408, \mathrm{p}<0,0005)$. A magasabb szintú stimuláció és anyai törődés tehát, elképzelésünkhöz hűen, magasabb teljesítménnyel járt együtt. A részterületek közül a legerősebb kapcsolat a BQ-val $(r=0,457$, $\mathrm{p}<0,0005)$, valamint az SzQ-val $(\mathrm{r}=0,390, \mathrm{p}=0,001)$ mutatkozott. Az otthoni környezet két összetevőjének teljesítményre gyakorolt hatását a 3. táblázat mutatja be.

A vizsgált öt szociodemográfiai rizikótényező (alacsonyabb, mint középiskolai végzettségű anya; munkanélküli vagy közfoglalkoztatott apa; négy vagy több egy háztartásban élő testvér; kisebbségi csoporthoz tartozás; apa nélküli család), nominális skálán elhelyezkedő változót, ugyanakkora súlyozással (1) egy skálaváltozóba sưrítettük (amelynek értéke: 1-5), ezáltal lehetőségünk nyílt korrelációt vizsgálni a rizikóindex és az FQ között. Elképzelésünknek megfelelően több rizikófaktor jelenléte a gyermek életében rosszabb teljesítménnyel járt együtt (FQ: $r=-0,476, p<0,0005$ ), s mindegyik részképesség- 
3. táblázat $\mid$ A HOME alskáláinak és a részképességek összefüggésének bemutatása

\begin{tabular}{llllll}
\hline & $\begin{array}{l}\text { Fejlődési } \\
\text { kvóciens } \\
(\mathrm{FQ})\end{array}$ & $\begin{array}{l}\text { Posturalis } \\
\text { adaptáció } \\
(\mathrm{PQ})\end{array}$ & $\begin{array}{l}\text { Szenzo- } \\
\text { motoros } \\
\text { koordiná- } \\
\text { ció }(\mathrm{KQ})\end{array}$ & $\begin{array}{l}\text { Beszéd- } \\
\text { készség } \\
(\mathrm{BQ})\end{array}$ & $\begin{array}{l}\text { Szociális } \\
\text { készség } \\
(\text { SzQ })\end{array}$ \\
\hline $\begin{array}{l}\text { Anyai } \\
\text { empátia }\end{array}$ & $0,423^{* *}$ & $0,400 * *$ & $0,376^{* *}$ & $0,413 * *$ & $0,424 * *$ \\
$\begin{array}{l}\text { Kognitív } \\
\text { stimuláció }\end{array}$ & $0,268^{*}$ & 0,167 & 0,213 & $0,357 * *$ & $0,241^{*}$ \\
\hline
\end{tabular}

Spearman-féle rangkorreláció, ${ }^{*} \mathrm{p}<0,01,{ }^{*} \mathrm{p}<0,05$.

4. táblázat |A részképességek medián értékeinek alakulása a SES-rizikópontszámok tükrében

\begin{tabular}{llllll}
\hline & $\begin{array}{l}\text { 0 SES- } \\
\text { rizikó- } \\
\text { tényezó }\end{array}$ & $\begin{array}{l}\text { 1 SES- } \\
\text { rizikó- } \\
\text { tényező }\end{array}$ & $\begin{array}{l}\text { 2 SES- } \\
\text { rizikó- } \\
\text { tényező }\end{array}$ & $\begin{array}{l}\text { 3 SES- } \\
\text { rizikó- } \\
\text { tényező }\end{array}$ & $\begin{array}{l}\text { 4 SES- } \\
\text { rizikó- } \\
\text { tényező }\end{array}$ \\
\hline $\begin{array}{l}\text { Posturalis adaptáció } \\
(\mathrm{PQ})\end{array}$ & 94,5 & 98 & 77,5 & 82 & 76 \\
$\begin{array}{l}\text { Szenzomotoros } \\
\text { koordináció (KQ) }\end{array}$ & 91,5 & 92 & 75,5 & 66 & 60 \\
$\begin{array}{l}\text { Beszédkészség (BQ) } \\
\begin{array}{l}\text { Szociális készség } \\
\text { (SzQ) }\end{array}\end{array}$ & 86 & 83 & 76 & 73 & 69 \\
\hline
\end{tabular}

5. táblázat |A két főkomponens részképességekkel való összefüggései Spearman-féle béta-együtthatók szemléltetésével

\begin{tabular}{llllll}
\hline & $\begin{array}{l}\text { Fejlődési } \\
\text { kvóciens } \\
(\mathrm{FQ})\end{array}$ & $\begin{array}{l}\text { Posturalis } \\
\text { adaptáció } \\
(\mathrm{PQ})\end{array}$ & $\begin{array}{l}\text { Szenzo- } \\
\text { motoros } \\
\text { koordiná- } \\
\text { ció }(\mathrm{KQ})\end{array}$ & $\begin{array}{l}\text { Beszéd- } \\
\text { készség } \\
(\mathrm{BQ})\end{array}$ & $\begin{array}{l}\text { Szociális } \\
\text { készség } \\
(\text { SzQ })\end{array}$ \\
\hline $\begin{array}{l}\text { Első } \\
\text { fókomponens } \\
\text { Második } \\
\text { fókomponens }\end{array}$ & $0,495^{* *}$ & $0,477^{* *}$ & $0,474^{* *}$ & $0,360 * *$ & $0,426 * *$ \\
\hline
\end{tabular}

Spearman-féle rangkorreláció, * ${ }^{*} \mathrm{p}<0,01,{ }^{*} \mathrm{p}<0,05$.

gel is szignifikáns, negatív irányú, közepesen erős korrelációt mutatott (4. táblázat).

\section{Modellalkotás}

A szignifikáns értékeket mutató változók struktúrájának feltérképezésére a faktoranalízis egy fajtáját, fókomponens-analízist végeztünk, s azt találtuk, hogy a fentebb említett változók hatása egymástól független dimenziók mentén közelíthető meg. Varimax-rotáció és Kaiser-normalizáció használatával változóink két komponensbe szerveződtek. Az első komponens a születési súlyt, az ötödik percben mért Apgar-értéket és a születés után kórházban eltöltött napok számát tartalmazta, amelynek magyarázó ereje 40,22\%-os volt. A második komponens 32,30\%-os magyarázó erővel a társas-környezeti ténye- zóket tartalmazta, mint a gyermek nélkülözése, az őt érő kognitív stimuláció és anyai empátiás odafordulás mértéke, valamint a szociodemográfiai rizikótényezők. Az így felállított modellünk 72,53\%-os magyarázó ereje igen erősnek bizonyult, s a vizsgált hatás majdnem háromnegyedét magyarázta. Végül pedig a lineáris regresszió analízis rámutatott, hogy mindkét komponens szignifikánsan befolyásolja a gyermek kétéves kori fejlődési értékeit (5. táblázat).

\section{Megbeszélés}

A tanulmányban részt vevő gyermekek $86,6 \%$-a érte el a Brunet és Lezine által ajánlott átlagos tartományt a fejlődésvizsgálat során, azaz 70 feletti FQ-t, 13,4\%-uknál pedig a valódi életkorukhoz képest megkésett fejlődést tapasztaltunk (korrekcióval számolva 6,6\%). Ez az arány valamivel magasabb, mint egy 2014-es nagyobb elemszámú $(\mathrm{n}=399)$ svéd vizsgálat során talált eredmény $(11,9 \%)$ [26]. A gyermekek korrigáltan számolt átlagpontszáma $(\mathrm{M}=93)$ azonban illeszkedik a nemzetközileg közölt eredmények sorába ( $\mathrm{M}=96$ [27]; $\mathrm{M}=94$ [28]).

\section{A pszichomotoros fejlödés részterületei és a nemi különbségek}

A vizsgálat során a négy részképesség közül a szociabilitás (szociális tevékenységekben való részvétel, étkezés, szobatisztaság vagy felnőttek irányába mutatott kapcsolatkészség) bizonyult a legfejlettebb területnek mindhárom súlyövezetben, ami megegyezik a nemzetközi vizsgálatok eredményeivel $[27,29]$. Ezt követte a nagymotoros mozgások területe, amely olyan készségeket takar, mint az egyensúlyozás (például: járás, lépcsőhasználat), a motoros tervezés és dinamikus múködés (például: labdajátékokban), beleértve a helyváltoztatást is. A sorban ez után a szenzomotoros koordináció, azaz a szemkéz koordinációt igénylő készségek, a finom motoros tervezés, valamint a gyermek tárgymanipulációs és tárgymegragadási képességei (például: rajzkészség, toronyépítés) következtek. Végül a legkevésbé fejlett részterületnek az expresszív-receptív beszédkészség mutatkozott, amely magába foglalja a gyermek szókincsének fejlettségét, verbális megértő képességét, valamint a tárgyak és képek megnevezési készségét. Egy másik, koraszülött gyermekek körében végzett magyar kutatás [14] szintén a verbális készségek elmaradására hívja fel a figyelmet.

Az általunk talált szignifikáns nemi differencia egybevág Romeo és mtsai 2010-es eredményeivel, viszont jóval nagyobb mértékü (differencia $=11$ ) [17], mint a Fily és mtsai által 2006-ban kimutatott eltérés (differencia = 3) [28]. Ezek a korai életkorban jelentkező nemi különbségek az időre született gyermekek fejlődésében is kimutathatók, amelyekre a szülők számára tartott pszichoedukáció során feltétlenül szükséges kitérni. 


\section{A születési súly és a pszichomotoros fejlódés kapcsolata}

A szakirodalommal, illetve napjaink kutatásaival szinkronban [16] a mi vizsgálatunk is azt mutatja, hogy a születési súly pozitívan korrelál a kétéves korban mért FQval, valamint a változó prediktív értéke jelen esetben is közepesen erős. Mivel kontrollcsoport illesztéséhez már nem volt alkalmunk a kutatás során, így referenciaértékként a Brunet és Lézine által leírt 100-as FQ-értéket tudjuk használni, amely a gyermek életkorának éppen megfelelő teljesítményt mutatja. A vizsgált LBW-csoportba tartozó gyermekek 93-as átlagteljesítménye tehát majdnem megegyezik az életkoruknak éppen megfelelő átlagos eredménnyel. Azonban az 1500 grammos határvonal alatti súllyal születettek kétéves kori neuromotoros fejlődésüket tekintve (VLBW: FQ = 83; ELBW: FQ = 77) jóval nagyobb rizikóval jellemezhetőek. Fontos kiemelni, hogy a „normális” teljesítmény nem egy pont, hanem egy tág intervallum, valamint megkésett fejlődésról csak 70 alatti érték esetében beszélhetünk.

\section{A társas-környezeti tényezők és a pszichomotoros fejlödés kapcsolata}

A gyermekpopulációt sújtó nélkülözés kiemelt társadalmi probléma napjainkban. Ahogy az UNICEF 2012-es kutatási eredményei is szemléltetik, Magyarországon ez az arány 31,9\% [21]. Az általunk vizsgált koraszülöttek körében ehhez nagymértékben hasonló eredményt kaptunk: 29,3\%-os arányban voltak jelen nélkülöző gyermekek a mintában. Azt találtuk, hogy mindhárom születési súlykategóriában alacsonyabb teljesítményt nyújtottak a kettő vagy több szükséglet tekintetében egyaránt nélkülöző gyermekek, mint nem nélkülöző társaik. A kapott eredmények a VLBW és az LBW, azaz a két magasabb súlykategóriában bizonyultak statisztikailag szignifikánsnak. Elmondhatjuk tehát, hogy a legéretlenebben világra jövő gyermekeknél a nélkülözésnek, mint külső környezeti komponensnek, kevésbé van hatása a kétéves kori fejlődési kvóciensre, mint az 1000 gramm fölött születetteknél. A részképességeket tekintve a gyermeket érintő nélkülözés a legerősebb összefüggést a szociális készségekkel, valamint a nagymozgásos fejlődéssel mutatta. Ez összhangban van azzal, amit a korábbi eredményeink mutatnak, miszerint a finom motorikát érintő készségek tekintetében erősebb a biológiai meghatározottság, míg a szociabilitást kevésbé magyarázza a biológiai komponens. Eredményeink illeszkednek a Demeter Endre kutatócsoportja [30] által találtakhoz, miszerint az alsó tagozatos, szegénységben élő gyermekek körében több mint 10\%-kal gyakoribb a súlyos beszédértési probléma, mint szegénységgel nem sújtott társaiknál, továbbá megfelelő anyagi háttérrel rendelkező társaikhoz képest veszélyeztetettebbek a tanulási zavarok tekintetében is. E zavarok megelőzésében nyújthat segítséget a korai életévekben történő szûrés, amely úgy tünik, már kétéves korban is rávilágíthat a problémás területekre.

$\mathrm{Az}$ otthoni környezet minőségi jellemzőinek kétéves kori FQ-ra feltételezett hatása is beigazolódott. Úgy tünik, a kognitív serkentés és az anyai empátiás odafordulás nagyobb mértéke magasabb fejlődési kvócienssel jár együtt. Ezen eredményünk egybecseng a Kalmár és Boronkai [31] által leírtakkal, miszerint az otthoni környezet minősége és a 8-10 éves kori IQ-pontszámok között erőteljes összefüggés áll fenn, továbbá úgy tünik, már a gyermek jóval korábbi életszakaszában is kimutatható ez a kapcsolat. Az anya empátiás viselkedésének, gyermekére való reagálásának, verbális válaszadásának, folyamatos kommunikációjának és meleg, szeretetteli attitüdjének kiemelt szerepe van a kétéves kori szociális és beszédkészségek színvonalának alakulásában. További fontos összetevő az anya részéről a gyermek szükségleteit tiszteletben tartó, cselekedetei és étkezési szokásai iránt elfogadó, nem korlátozó és akadályozó attitüd, valamint a fizikai büntetés kerülése. Összességében tehát azt látjuk, hogy az anya szenzitív, empátiás odafordulása már a kétéves kori szociális és beszédkészségbeli fejlődés szempontjából is kiemelt fontosságú tényező.

A szociodemográfiai változók tekintetében a legerősebb összefüggést a gyermek teljesítményével az anya iskolázottsága, valamint a család kisebbségi csoporthoz való tartozása mutatta. A gyermek fejlődésében az anya végzettségét tekintve a kevesebb, mint nyolc általános iskolai osztály elvégzése tekinthető veszélyeztető faktornak a gyermek fejlődésében. A kisebbségi csoporthoz való tartozás befolyása a gyermekkori fejlődésre distalis, azaz közvetett csatornaként írható le, amely valószínúsíthetően a kulturális szokásoktól kezdve számos egyéb proximális tényezőn keresztül fejti ki hatását. További nem elhanyagolható összefüggést találtunk az apa foglalkoztatottságának színvonalával kapcsolatban is, ahol a munkanélküli és a közmunkát végző státusz tekinthető rizikókategóriának. Fily és mtsai [28] hasonló tényezőket vizsgáltak a koraszülött gyermekek kétéves kori pszichomotoros fejlődésével összefüggésben, azonban jóval nagyobb mintán $(\mathrm{N}=380)$, így érdemesnek tartom bemutatni az eredményeink összehasonlítását (6. táblázat).

Összegezve: Az eredmények azt mutatják, hogy a gyermek életében nulla vagy egy rizikófaktor jelenléte nem okoz teljesítménycsökkenést, azonban a kettő, három, valamint négy rizikóval élő gyermekek kétéves kori teljesítménye fokozatos csökkenést mutat a faktorok számának növekedésével.

\section{Fejlödési modell}

A vizsgált koraszülött gyermekek kétéves kori $\mathrm{FQ}$-jának vonatkozásában mind a biológiai (születési súly, Apgarértékek, kórházi tartózkodás hossza), mind a társas-környezeti komponens (otthoni környezet minősége, nélkülözés, szociodemográfiai jellemzők) fontos befolyásoló tényezőnek tünik, továbbá mind a négy részképességre is 
Fily és mtsai (2006) adatainak összehasonlítása a saját adataink kal (M, P-value)

\begin{tabular}{|c|c|c|c|c|}
\hline & \multicolumn{2}{|c|}{ Fily és mtsai (2006) } & \multicolumn{2}{|c|}{ Jelen kutatás (2015) } \\
\hline & \multicolumn{4}{|c|}{ Szociodemográfiai változók és korrigált FQ } \\
\hline & $\begin{array}{l}\text { Mean korr. } \\
\text { FQ }\end{array}$ & P-value & $\begin{array}{l}\text { Mean korr. } \\
\text { FQ }\end{array}$ & P-value \\
\hline \multicolumn{5}{|c|}{ Legmagasabb (anyai) iskolai végzettség } \\
\hline$\geq$ középiskola & 99 & $<0,01$ ** & 95 & $<0,01$ ** \\
\hline < középiskola & 92 & & 83 & \\
\hline \multicolumn{5}{|c|}{ Apai foglalkoztatottság } \\
\hline $\begin{array}{l}\text { Magas vagy } \\
\text { középszintú } \\
\text { dolgozó }\end{array}$ & 96 & $<0,01$ ** & 94 & $<0,01$ * * \\
\hline $\begin{array}{l}\text { Munkanélküli, } \\
\text { közfoglalkoz- } \\
\text { tatott }\end{array}$ & 85 & & 82 & \\
\hline \multicolumn{5}{|c|}{ Egy háztartásban éló gyermekek száma } \\
\hline 1 & 95 & $=0,08$ & 94 & $=0,5$ \\
\hline $2-3$ & 93 & & 94 & \\
\hline$\geq 4$ & 90 & & 88 & \\
\hline
\end{tabular}

${ }^{*}{ }^{*} \mathrm{p}<0,01,{ }^{*} \mathrm{p}<0,05$

szignifikáns hatást gyakorolnak. A biológiai komponens valamivel erősebb összefüggést mutat a nagymozgások, a szenzomotoros koordináció, valamint a szociabilitás területeivel, azonban a felmért környezeti tényezők hatása sem elhanyagolható. Az expresszív-receptív beszédkészség ellenben a társas-környezeti tényezőkkel áll szorosabb kapcsolatban, úgymint az anya empátiás gondoskodása, reaktibilitása, iskolai végzettsége vagy a család kisebbségi csoporthoz való tartozása.

A születési súlyt tekintve 1000 grammnál húzható meg egyfajta mesterséges határmezsgye, amely alatt a biológiai sérülékenység erősebb prediktora a kétéves kori pszichomotoros fejlődésnek, fölötte azonban a társaskörnyezeti komponens fokozottabb befolyással bír. A gyermekek komplex vizsgálata során azonban egyik tényező hatása sem elhanyagolható.

\section{Következtetések}

Napjainkban a koraszülés népbetegségnek tekinthető, amelyben majdnem minden tizedik újszülött és családja érintett. A lehetséges szövődmények azonban nemcsak a gyermekek, szülők és családok mikroszintjén okoznak káros hatásokat, hanem megmutatkoznak az egészségügyi, oktatási és gazdasági rendszer által alkotott makrokörnyezeti szinten is. A koraszülöttség számos szomatikus kórképen túl rizikója a specifikus tanulási, figyelmi és koncentrációs nehézségeknek, továbbá egyéb teljesítmény-, viselkedés- és részképességzavaroknak is.

Későbbi vizsgálataink során a pontosabb diagnosztika érdekében tervezzük a legkorszerúbb fejlődésdiagnosztikai eszköz, a Bayley III. csecsemő-pszichodiagnosztikai és -szürő teszt (Bayley Scales of Infant and Toddler Development and Screening Test [32]) alkalmazását, amelynek standardizációs munkálatai jelenleg is zajlanak hazánkban. E vizsgálóeljárás szélesebb körben méri fel a kisgyermekek fejlődési szintjét, pontosabb és precízebb képet adva, mint a Brunet-Lézine-teszt, valamint alkalmas a 30-42 hónapos gyermekek vizsgálatára egyaránt.

A szakirodalomban leírtakra és kutatásunk eredményeire alapozva ajánljuk a szekunder, valamint tercier prevenció feladatkörébe tartozó intervenciók, a korai fejlesztés terápiás körének minél korábbi életszakaszban történő megkezdését, amely a már felismert esetek célzott ellátásán keresztül képes az esetleges káros szövődményeket és következményeket széles körben megelőzni, redukálni, valamint az esetlegesen sérült készségek hatékony felzárkózását elősegíteni.

Anyagi támogatás: A szerzők anyagi támogatásban nem részesültek.

Szerzôi munkamegosztás: K. F.: A vizsgálati téma felvetése, szakirodalom gyưjtése és feldolgozása, hipotézisek megalkotása, vizsgálatok lefolytatása, adatok feldolgozása, statisztikai elemzések, kézirat megszövegezése. N. B. E.: A vizsgálati téma felvetése, hipotézisek megalkotása, útmutatás a vizsgálat lefolytatásához, eredmények és összefüggések értelmezése, kézirat megszövegezése. A cikk végleges változatát mindkét szerző elolvasta és jóváhagyta.

Érdekeltségek: A szerzőknek nincsenek érdekeltségeik.

\section{Köszönetnyilvánítás}

A szerzők ezúton mondanak köszönetet Prof. Dr. Balla Györgynek, a Debreceni Egyetem, Klinikai Központ, Gyermekgyógyászati Intézet igazgatójának, hogy lehetővé tette a koraszülött gyermekek fejlődésvizsgálatainak elvégzését.

\section{Irodalom}

[1] Szilvási, L.: Inequalities and child development - intervention options. In: Sallai, É. (ed.): The context of social inequalities, the non traditional family models, parental behavior and the child development. [Egyenlőtlenségek és gyermeki fejlődés - beavatkozási lehetőségek. In: Sallai, É. (szerk.): Társadalmi egyenlőtlenségek, a nem hagyományos családmodell, a szülői viselkedés és a gyermekek fejlődésének összefüggései.] Educatio Társadalmi Szolgáltató Közhasznú Társaság, Budapest, 2008, 13-37. [Hungarian]

[2] WHO recommendations on interventions to improve preterm birth outcomes. World Health Organization, France, 2015.

[3] Frey, H. A., Klebanoff, M. A.: The epidemiology, etiology and costs of preterm birth. Semin. Fetal Neonatal Med., 2016, 21(2), 68-73.

[4] Görbe, É.: Premature baby in the family. [Koraszülött a családban.] White Golden Book Kft., Budapest, 2004. [Hungarian]

[5] Danis I., Kalmár M.: The nature and models of development. In: Danis, I., Farkas, M., Herczog, M., et al. (eds.): The genes to society: the early childhood development areas. [A fejlödés ter- 
mészete és modelljei. In: Danis, I., Farkas, M., et al. (szerk.): A génektól a társadalomig: a koragyermekkori fejlódés színterei. Nemzeti Család- és Szociálpolitikai Intézet, Budapest, 2011, 76-124. [Hungarian]

[6] Woythaler, M. A., McCormick, M. C., Smith, V. C.: Late preterm infants have worse 24-month neurodevelopmental outcomes than term infants. Pediatrics, 2011, 127(3), e622-e629.

[7] Potijk, M. R., de Winter, A. F., Bos, A. F., et al.: Higher rates of behavioural and emotional problems at preschool age in children born moderately preterm. Arch. Dis. Child., 2012, 97(2), 112117.

[8] Talge, N. M., Holzman, C., Wang, J., et al.: Late-preterm birth and its association with cognitive and socioemotional outcoes at 6 years of age. Pediatrics, 2010, 126(6), 1124-1131.

[9] Kalmár, M.: The brain development threatening factors and possibilities of averting threats. In: Danis, I., Farkas, M., Herczog, M., et al. (eds.): The genes to society: the early childhood development areas. [Az agy fejlődését veszélyeztető tényezők és veszélyek elhárításának lehetőségei. In: Danis, I., Farkas, M., Herczog, M., et al. (szerk.): A génektől a társadalomig: a koragyermekkori fejlődés színterei.] Nemzeti Család- és Szociálpolitikai Intézet, Budapest, 2011, 206-226. [Hungarian]

[10] Machay, T., Balla, Gy., Hajdi, Gy.: Neonatology: fetal and neonatal infections. In: Maródi, L. (ed.): Paediatrics. [Neonatológia: magzati és újszülöttkori fertőzések. In: Maródi, L. (szerk.): Gyermekgyógyászat.] Medicina Könyvkiadó, Budapest, 2014, 291-374. [Hungarian]

[11] Decsi, T.: The healthy children growth and development. In: Boda, M., Sulyok, E. (eds.): Pediatrics. [Az egészséges gyermek növekedése és fejlődése. In: Boda, M., Sulyok, E. (szerk.): Gyermekgyógyászat.] Medicina Könyvkiadó, Budapest, 2008, 23-45. [Hungarian]

[12] Qiu, X., Lee, S. K., Tan, K., et al.: Comparison of singleton and multiple-birth outcomes of infants born at or before 32 weeks of gestation. Obstet. Gynecol., 2008, 111(2 Pt 1), 365-371.

[13] Aylward, G. P.: Neonatology, prematurity, NICU, and developmental issues. In: Roberts, M. C. (ed.): Handbook of Pediatric Psychology. 3rd ed. Guilford Press, New York, 2003, 253-268.

[14] Szanati, D. V.: The role of speech terapist-health psychologist monitoring children born prematurely. [A logopédus-egészségpszichológus szerepe a koraszülött gyermekek utánvizsgálatában.] Gyógypedagógiai Szemle, 2011, 39(3-4), 188-195. [Hungarian]

[15] Ittzésné, N. B., Vekerdy, Zs., Lakatos, L.: Conduct and behavioral characteristics extreme low birth weight $(1000 \mathrm{~g})$ children at age of 8-11. [Magatartási és viselkedési jellegzetességek extrém kis születési súlyú (1000 g) gyermekeknél 8-11 éves korban.] Gyermekgyógyászat, 1991, 42(4), 517-520. [Hungarian]

[16] Constantinou, C. J., Adamson-Macedo, E. N., Mirmiran, M., et al.: Neurobehavioral assessment predicts differential outcome between VLBW and ELBW preterm infants. J. Perinatol., 2005, 25(12), 788-793.

[17] Romeo, D. M., Di Stefano, A., Conversano, M., et al.: Neurodevelopmental outcome at 12 and 18 months in late preterm infants. Eur. J. Paediatr. Neurol., 2010, 14(6), 503-507.

[18] Estefánné, V. M.: Results of school successfulness and longitudinal psyho-diagnostic testing among children born prematurely. [Koraszülött gyermekek longitudinális, pszichodiagnosztikai vizsgálatának és iskolai beválásának eredményei.] Alkalmazott Pszichológia, 2003, 5(2), 5-24. [Hungarian]
[19] Ribiczey, N.: Environmental impacts and intellectual develop ment - different approaches to capture the relevant aspects of the environment. [Környezeti hatások és intellektuális fejlődés Különböző megközelítések a környezet releváns aspektusainak megragadására.] Gyógypedagógiai Szemle, 2010, 38(1), 46-60. Avaliable from: http://www.prae.hu/prae/gyosze.php?menu_ id $=102 \&$ jid $=31 \&$ jaid $=457$ [Hungarian]

[20] Nagy, B.: Psychotherapy and rehabilitation in child benefit in the light of special needs children studies. [Pszichoterápia és rehabilitáció a gyermekellátásban a speciális szükségletú gyermekekkel végzett vizsgálatok tükrében.] Didakt Kiadó, Debrecen, 2007. [Hungarian]

[21] Farkas, M., Csiky, E.: The Brunet-Lézine scale use for early detection of childhood psychomotor development disorders. [A Brunet-Lézine-féle vizsgálati módszer alkalmazása a gyermekkori pszichomotors fejlődés zavarainak korai felismerésében.] Múvelődési Minisztérium, Budapest, 1980. [Hungarian]

[22] UNICEF: Measuring child poverty. New league tables of child poverty in the world's rich countries. Innocenti Report Card 10. UNICEF Innocenti Research Centre, Florence, 2012.

[23] Bradley, R. H., Caldwell, B. M., Corwyn, R. F.: The Child Care HOME Inventories: assessing the quality of family child care homes. ECRQ, 2003, 18, 294-309.

[24] Sameroff, A. J., Seifer, R.: Familial risk and child competence. Child Develop., 1983, 54(5), 1254-1268.

[25] Sameroff, A. J., Seifer, R., Baldwin, A., et al.: Stability of intelligence from preschool to adolescence: the influence of social and family risk factors. Child Develop., 1993, 64(1), 80-97.

[26] Månsson, J., Stjerngvist, K.: Children born extremely preterm show significant lower cognitive, language and motor function levels compared with children born at term, as measured by the Bayley-III at 2.5 years. Acta Paediatr., 2014, 103(5), 504-511.

[27] Charkaluk, M. L., Truffert, P., Fily, A., et al.: Neurodevelopment of children born very preterm and free of severe disabilities: the Nord-Pas de Calais Epipage cohort study. Acta Peadiatr., 2010, 99(5), 684-689.

[28] Fily, A., Pierrat, V., Delporte, V., et al.: Factors associated with neurodevelopmental outcome at 2 years after very preterm birth: the population-based Nord-Pas-de-Calais EPIPAGE cohort. Pediatrics, 2006, 117(2), 357-366.

[29] Flamant C., Branger B., Nguyen The Tich, S., et al.: Parent-completed developmental screening in premature children: a valid tool for follow-up programs. PLoS ONE, 2011, 6(5), e20004.

[30] Demeter, E.: Child poverty's perception among teachers in Csepel. [Kutatási beszámoló. A gyermekszegénység percepciója a csepeli pedagógusok körében.] ELTE Társadalomtudományi Szakkollégium, Budapest, 2006. [Hungarian]

[31] Kalmár, M., Boronkai, J.: The role of quality of home environment in preterm children long-term intellectual development. [Az otthoni környezet minőségének szerepe koraszülött gyerekek hosszú távú értelmi fejlődésében.] Magyar Pszichológiai Szemle, 2001, 56(3), 387-410. [Hungarian]

[32] Bayley, N.: Bayley Scales of Infant and Toddler Development Third edition. The Psychological Corporation, San Antonio, TX, 2006.

(Kenyhercz Flóra, Miskolc, Bezerédi I. u. 30., 3529 e-mail: k.flora212@gmail.com) 